\title{
BLACK LIVES MATTER: DECRYPTING ENCRYPTED RACISM
}

\author{
Basil Ugorji \\ Nova Southeastern University
}

\section{Introduction: Preliminary Considerations}

The phrase "Black Lives Matter," an emerging "Black liberation movement" of the twenty-first century, has dominated both the public and private discourses in the United States. Since its creation in 2012 after the extrajudicial killing of a 17-year-old African American boy, Trayvon Martin, by a Sanford, Florida community vigilante, George Zimmerman, who was acquitted by a jury on the basis of self-defense under Florida's "Stand Your Ground Statute," legally known as "Justifiable Use of Force" (Florida Legislature, 1995-2016, XLVI, Ch. 776), the Black Lives Matter movement has mobilized millions of African Americans and their sympathizers to fight against the killings of African Americans and police brutality; to demand justice, equality, equity and fairness; and to assert their claims for fundamental human rights and dignity.

The claims put forward by the Black Lives Matter movement, though widely accepted by the group's sympathizers, have met with criticism from those who believe that all lives, irrespective of their ethnicity, race, religion, gender or social status, matter. It is argued by the proponents of "All Lives Matter" that it is unfair to focus only on the African American issues without also acknowledging the contributions and sacrifices people from the other communities make to protect all citizens and the entire country, including the heroic sacrifices of the police. Based on this, the phrases All Lives Matter, Native Lives Matter, Latino Lives Matter, Blue Lives Matter, and Police Lives Matter, sprang up in direct response to "activists who have mobilized against police brutality and attacks on black lives" (Townes, 2015, para. 3).

Although the arguments of the proponents of all lives matter may appear to be objective and universal, many prominent leaders in America believe that the statement "black lives matter" is a legitimate one. Explaining the legitimacy of "black lives matter" and why it should be taken seriously, President Barack Obama, as cited in Townes (2015), opines:

I think the reason that the organizers used the phrase 'black lives matter' was not because they were suggesting nobody else's lives matter. What they were sug- 
gesting was, there is a specific problem that is happening in the African-American community that's not happening in other communities. And that is a legitimate issue that we've got to address. (para. 2)

This unique problem to the African American community that President Obama refers to is linked to police brutality, killings of unarmed black people, and to some extent, unjustified imprisonment of the African American youth for minor offenses. As many African American critics have pointed out, there is a "disproportionate number of prisoners of color in this country [United States]" which they believe is due to "the racial discriminatory practices within the legal and law enforcement systems" (Tyson, 2015, p. 351-352). For these reasons, some writers argue that "we don't say 'all lives matter,' because when it comes to police brutality, not all bodies face the same levels of dehumanization and violence that black bodies do" (Brammer, 2015, para. 13).

This article does not intend to pursue the public debate on whether Black Lives Matter is legitimate or whether All Lives Matter should receive equal attention as many authors and commentators have done. In light of the revealed intentional discrimination against the African American community on the basis of race through police brutality, court practices, and other racially motivated activities; and knowing that these intentional, willfully committed discriminatory practices are in violation of the Fourteenth Amendment and other federal laws; this paper seeks to study and affirm that the underlying issue the Black Lives Matter movement is militating and fighting against is encrypted racism. The term encrypted racism is inspired by Restrepo and Hincapíe's "The Encrypted Constitution: A New Paradigm of Oppression," (2013) which argues that:

The first purpose of encryption is the disguising of all dimensions of power. With the encryption of technolegal language and, therefore, procedures, protocols and decisions, subtle manifestations of power become undetectable to anyone who does not have the linguistic knowledge to break the encryption. Thus, encryption depends on the existence of a group that has access to the formulae of encryption and another group that completely ignores them. The latter, being unauthorized readers, are open to manipulation. (p. 12)

Encrypted racism as it is used in this paper shows that the encrypted racist knows and understands the underlying principles of structural racism and violence but cannot overtly and openly discriminate against the African American community because open discrimination and structural 
racism are prohibited and made illegal by the Civil Rights Act of 1964 and other Federal Laws. The main argument of this paper is that the Civil Rights Act of 1964 passed by the 88th Congress (1963-1965) and signed into law on July 2, 1964 by President Lyndon B. Johnson ended overt structural racism but, unfortunately, did not end encrypted racism, which is a covert form of racial discrimination. Instead, the official prohibition of overt structural racism gave birth to this new form of racial discrimination that is intentionally concealed by the encrypted racists, but hidden from the victimized, de-humanized, terrorized and exploited African American community.

Although both structural racism and encrypted racism involve a position of power or authority, as will be detailed in the subsequent sections, what makes encrypted racism different from structural racism is that the latter was institutionalized and considered legal before the adoption of the Civil Rights Act of 1964, while the former is individually concealed and could be seen as illegal only when, or if and only if, it is decrypted and proven by higher authorities. Encrypted racism invests some form of pseudopower to the encrypted racist who in turn uses it to manipulate the powerless, vulnerable, and unprivileged African Americans. "The key to power as domination in our pseudodemocratic, globalized world is its encryption. Our task is to develop strategies for its decryption" (Restrepo and Hincapíe, 2013, p. 1). By way of analogy between the Civil Rights Movement led by Dr. Martin Luther King, Jr. and the Black Lives Matter movement led by Patrisse Cullors, Opal Tometi, and Alicia Garza, this paper affirms that just as the Civil Rights Movement was instrumental in ending overt structural racism, open discrimination and segregation in the United States, the Black Lives Matter movement has been bravely instrumental in decrypting encrypted racism in the United States - a form of racism that has been widely practiced by many individuals who are in a position of power including law enforcement officers.

A study on the agitation of the Black Lives Matter movement will not be complete without an examination of the theoretical assumptions underlying race relations in the United States. For this reason, this article seeks to draw inspiration from four relevant theories. The first is "African American Criticism," a critical theory that analyzes the racial issues that have characterized African American history since "The Middle Passage: the transportation of African captives across the Atlantic Ocean" to the United States where they were subjugated as slaves for many centuries (Tyson, 2015, p. 344). The second is Kymlicka's (1995) "Multicultural Citizenship: A Liberal Theory of Minority Rights" that recognizes and accords «group-differentiated rights» to particular groups that have suffered historical racism, discrimination and marginalization (for exam- 
ple, the African American community). The third is Galtung's (1969) theory of structural violence which could be understood from the distinction between "direct and indirect violence." While direct violence captures the authors explanation of physical violence, indirect violence represents structures of oppression that prevent a section of the citizenry from having access to their basic human needs and rights thereby forcing people's "actual somatic and mental realizations to be below their potential realizations" (Galtung, 1969, p. 168). And the fourth is Burton's (2001) critique of the "traditional power-elite structure" - a structure typified in the "we-they" mentality-, which holds that individuals who are subjected to structural violence by the institutions and norms inherent in the power-elite structure will definitely respond using different behavioral approaches, including violence and social disobedience.

Through the lenses of these social conflict theories, this article critically analyzes the important shift that has occurred in the history of America, that is, a transition from overt structural racism to encrypted racism. In doing this, efforts are made to highlight two crucial tactics inherent in both forms of racism; one is slavery, open discrimination and overt segregation characterizing structural racism, the other is police brutality and the killings of unarmed black people as examples of encrypted racism. In the end, the role of the Black Lives Matter movement in decrypting encrypted racism is examined and articulated.

\section{STRUCTURAL RACisM}

The advocacy of the Black Lives Matter movement goes beyond the on-going police brutality and killings of the African American people and African immigrants. The founders of this movement categorically stated on their website, \#BlackLivesMatter at http://blacklivesmatter.com/ that "It centers those that have been marginalized within Black liberation movements, making it a tactic to (re)build the Black liberation movement." Based on this article's assessment, the Black Lives Matter movement is fighting against encrypted racism. However, one cannot understand encrypted racism in the United States without recourse to structural racism, for structural racism engendered encrypted racism during the many centuries of African American nonviolent activism and the intercourse this activism had with legislations, making encrypted racism the spawn of structural racism.

Before we examine the historical realities surrounding racism in the United States, it is important to reflect on the social conflict theories mentioned above while highlighting their relevance to the subject matter. We begin by defining the terms: racism, structure, and encryption. Racism is defined as "the unequal power relations that grow from the sociopolitical domination of one race by another and that result in systematic 
discriminatory practices (for example, segregation, domination, and persecution)" (Tyson, 2015, p. 344). Racism conceived in this way could be explained from the ideological belief in the superior "other," that is, the superiority of the dominant race over the dominated race. For this reason, many African American critical theorists distinguish other terminologies associated with racism, including but not limited to racialism, racialist and racist. Racialism is "the belief in racial superiority, inferiority, and purity based on the conviction that moral and intellectual characteristics, just like physical characteristics, are biological properties that differentiate the races" (Tyson, 2015, p. 344). A racialist is therefore anyone who holds such beliefs in racial superiority, inferiority, and purity. And a racist is anyone who is in "a position of power as a member of the politically dominant group" who indulges in systematic discriminatory practices, "for example, denying qualified persons of color employment, housing, education, or anything else to which they're entitled" (Tyson, 2015 , p. 344). With these conceptual definitions, it becomes easier for us to understand structural racism and encrypted racism.

The expression, structural racism, contains an important word of which a reflective examination will aid our understanding of the term. The word to be examined is: structure. Structure could be defined in different ways, but for the purpose of this paper, the definitions provided by Oxford Dictionary and Learners Dictionary will suffice. For the former, structure means to "Construct or arrange according to a plan; to give a pattern or organization to something" (Definition of structure in English, n.d. In Oxford's online dictionary); and according to the latter it is "the way that something is built, arranged, or organized" (Learner's definition of structure, n.d. In Merriam-Webster's online learner's dictionary). The two definitions put together suggest that before the creation of a structure, there was a plan, a conscious decision to arrange or organize something according to that plan, followed by an execution of the plan and a gradual, coerced compliance resulting in the formation of a pattern. A repetition of this process will give people a seemingly false sense of a structure - an eternal, immutable, unchangeable, fixed, static, constant and universally acceptable way of living that remains irrevocable - the way that something is made. In light of this definition, we can understand how generations of European people constructed, were educated and educated their descendants in, structures of racism without realizing the level of damage, injury and injustice they were inflicting on the other races, especially the black race.

The accumulated injustices orchestrated by the structures of racism against the African Americans are at the core of the agitation of the Black Lives Matter movement for justice and equal treatment. From a theoretical perspective, the Black Lives Matter movement agitation could 
be understood from the "African American Criticism," a critical theory that analyzes the racial issues that have characterized African American history since "The Middle Passage: the transportation of African captives across the Atlantic Ocean" to the United States where they were subjugated as slaves for many centuries (Tyson, 2015, p. 344). In order to explain the challenges faced by the African Americans as a result of slavery, racism, and discrimination, African American critics make use of "Critical Race Theory" (Tyson, 2015, pp. 352 -368). This theory is primarily concerned with an examination of our interactions from a race perspective as well as inquiries into how these interactions affect the everyday well-being of minorities, especially the African American community. By analyzing the overt and covert outcomes of the interactions between African Americans and the dominant European (self-proclaimed white) population in the United States, Tyson (2015) affirms that: "critical race theory examines the ways in which details of our everyday lives are related to race, though we may not realize it, and studies the complex beliefs that underlie what seem to be simple, commonplace assumptions about race in order to show where and how racism still thrives in its 'undercover' existence" (p. 352).

The questions that come to mind are: How is critical race theory relevant to the Black Lives Matter movement? Why is racial discrimination still an issue in America given the fact that the overt racial discriminatory practices perpetrated against the African Americans during the pre-Civil Rights Movement period were legally put to an end by the Civil Rights Acts of 1964, and considering that the current president of the United States is also of African American descent? To answer the first question, it is important to highlight the fact that both the proponents and opponents of the Black Lives Matter movement do not disagree on the racial issues that led to the emergence of the movement. Their disagreement is on the manner or way in which the Black Lives Matter movement activists try to achieve their goals. To show that the Black Lives Matter movement has a legitimate claim for equality, equity and other human rights, their critics, especially the proponents of All Lives Matter movement, by implication include the African Americans in the category of "All Lives" that matter as they advocate for equality and equity for all citizens irrespective of race, gender, religion, ability, nationality, and so on.

The problem with the use of "All Lives Matter" is that it fails to acknowledge historical and racial realities and past injustices that characterize the United States. For this reason, many liberal theorists of minority rights and multiculturalism argue that such generic categorization as "All Lives Matter" rules out "group-specific rights" or, put differently, "group-differentiated rights" (Kymlicka, 1995). In order to recognize and 
accord «group-differentiated rights» to particular groups that have suffered historical racism, discrimination and marginalization (for example, the African American community), Will Kymlicka (1995), one of the leading theorists on multiculturalism, has been actively involved in philosophical analysis, scholarly research and policy formulation on issues related to minority group rights. In his book, "Multicultural Citizenship: A Liberal Theory of Minority Rights," Kymlicka (1995), like many critical race theorists, believes that liberalism as it has been understood and used in formulating government policies has failed in promoting and defending the rights of the minorities who are living within a larger society, for example, the African American community in the United States. The conventional idea about liberalism is that "the liberal commitment to individual liberty is opposed to the acceptance of collective rights; and that the liberal commitment to universal rights is opposed to the acceptance of the rights of specific groups" (Kymlicka, 1995, p. 68). For Kymlicka (1995), this "politics of benign neglect" that has led to a continuous marginalization of the minorities should be corrected (pp. 107-108).

In a similar manner, critical race theorists believe that liberal principles as they have been formulated and understood are limited when put into practice in a multicultural society. The idea is that since conservatism has vehemently opposed any policy proposal that is viewed to be of benefit to the oppressed minorities, liberalism should not remain as conciliatory or moderate as it has been on racial issues. It is true that liberalism has been helpful in, for example, passing the bill that desegregated schools, but critical race theorists believe that it has done "nothing to remedy the fact that schools are still segregated not by law but by poverty" (Tyson, 2015, p. 364). Also, even though the Constitution affirms equal opportunity for all citizens, discrimination still occurs every day in the areas of employment and housing. The Constitution has not been successful in stopping covert racism and discriminatory practices against the African Americans who continue to be at a disadvantage, while the European (white) people continue to enjoy privileges in almost all the sectors of society.

Structural racism could be described as privileging one section of the society over the other - the minorities. The privileged group members - the white population - are given easy access to the dividends of democratic governance while the unprivileged minorities are intentionally, covertly or overtly, restricted from having access to the same dividends provided by democratic governance. What then is white privilege? How could the unprivileged African American children who, for no choice of their own, are born into poverty, poor neighborhoods, unequipped schools, and circumstances that warrant prejudice, surveillance, stop and 
frisk, and sometimes police brutality, be assisted in order to compete with their white counterparts?

"White privilege," according to Delgado \& Stefancic (2001, as cited in Tyson, 2015) could be defined as "the myriad of social advantages, benefits, and courtesies that come with being a member of the dominant race" (p. 361). In other words, "white privilege is a form of everyday racism because the whole notion of privilege rests on the concept of disadvantage" (Tyson, 2015, p. 362). To give up white privilege, Wildman (1996, as cited in Tyson, 2015) believes is "to stop pretending that race does not matter" (p. 363). The notion of privilege is very relevant to understanding of the African American situation. To be born into an African American family does not depend on the choice of an African American child. In other words, it is based on luck and not on choice; and for this reason, the African American child should not be punished because of a choice or decision he or she did not make. From this perspective, Kymlicka (1995) strongly believes that "group-specific rights" or "group-differentiated rights" are justified "within a liberal egalitarian theory. . .which emphasizes the importance of rectifying unchosen inequalities" (p. 109). Stretching this line of thought a little bit further and to its logical conclusion, one could argue that the claims of the "Black Lives Matter" movement should equally be considered justifiable, for these claims are vital to understanding how the victims of structural or institutional racism and violence feel.

One of the social conflict theorists whose work on "structural violence" remains relevant to the understanding of structural racism or institutionalized racism in the United States is Galtung (1969). Galtung's (1969) notion of structural violence which draws on direct and indirect violence, among other things, could help us understand how the structures and institutions designed to engender racial discrimination against the African American race and other minorities function. While direct violence captures the authors explanation of physical violence, indirect violence represents structures of oppression that prevent a section of the citizenry from having access to their basic human needs and rights thereby forcing people's "actual somatic and mental realizations to be below their potential realizations" (Galtung, 1969, p. 168).

By way of analogy, one could argue that just as the indigenes of the Niger Delta of Nigeria have suffered the unbearable effects of structural violence in the hands of the Nigerian government and multinational oil companies, the African American experience in the United Sates, beginning from the time of the arrival of the first slaves, through the time of Emancipation, the Civil Rights Act, and until the recent emergence of the Black Lives Matter movement, has been marked by structural violence. In the case of Nigeria, the economy of Nigeria is primarily based on the 
natural resources, especially the oil extraction in the Niger Delta region. The dividends from the sale of oil that comes from the Niger Delta are used to develop the other major cities, enrich the foreign extraction campaigns and their expatriate employees, pay politicians as well as build roads, schools, and other infrastructures in the other cities. However, the people of the Niger Delta not only suffer the adverse effects of the oil extraction - for example environmental pollution and destruction of their God given habitat - but they have been neglected for centuries, silenced, subjected to abject poverty and inhumane treatment. This example spontaneously came to mind as I was reading Galtung's (1969) explanations of structural violence. Similarly, the African American experience of structural violence according to Tyson (2015) is due to:

"the incorporation of racist policies and practices in the institutions by which a society operates: for example, education; federal, state, and local governments; the law, both in terms of what is written on the books and how it is implemented by the courts and by police officials; health care, and the corporate world" (p. 345).

Dismantling the structures that are based on racist policies requires a nonviolent or sometimes violent and costly challenge of the institutions and structures of oppression. In the same way that the Niger Delta leaders, championed by Ken Saro-Wiwa, waged a nonviolent fight for justice against the then Nigerian military dictators, for which Saro-Wiwa and many others paid the prize of freedom with their lives as the military dictators condemned them to death without due trial, Martin Luther King Jr. "became the leader of the Civil Rights Movement" that used nonviolent means to legally end official racial discrimination in the United States (Lemert, 2013, p. 263). Unfortunately, Dr. King "was murdered in Memphis in 1968 as he was organizing the 'poor people's march' on Washington" (Lemert, 2013, p. 263). The assassination of nonviolent activists like Dr. King and Ken Saro-Wiwa teaches us an important lesson about structural violence. According to Galtung (1969):

When the structure is threatened, those who benefit from structural violence, above all those who are at the top, will try to preserve the status quo so well geared to protect their interests. By observing the activities of various groups and persons when a structure is threatened, and more particularly by noticing who comes to the rescue of the structure, an operational test is introduced that can be used to rank the members of the structure in terms of their interest in maintaining the structure (p. 179).

The question that comes to mind is: How long will the guardians of structural violence continue to maintain the structure? In the case of the United States, it took so many decades to start the process of dismantling 
the structures embedded in racial discrimination, and as the Black Lives Matter movement has shown, there is a lot of work to be done.

In line with Galtung's (1969) idea of structural violence, Burton (2001), in his critique of the "traditional power-elite structure" - a structure typified in the "we-they" mentality- believes that individuals who are subjected to structural violence by the institutions and norms inherent in the power-elite structure will definitely respond using different behavioral approaches, including violence and social disobedience. Based on the belief in the crisis of civilization, the author highlights the fact that the use of coercion is no longer sufficient to maintain structural violence against its victims. The advances in communication technology, for example, the use of social media and the ability to organize and rally supporters, can easily bring about the needed social change - change in power dynamics, restoration of justice, and above all the end of structural violence in the society.

\section{ENCRYPTED RACISM}

As discussed in the preceding sections - the sections that address preliminary considerations and structural racism - one of the differences between structural racism and encrypted racism is that during the structural racism era, African Americans were legally labeled non-citizens or aliens and were stripped off of voting rights and the opportunity to mobilize for advocacy, action and justice, while undergoing a high risk of being killed by the European (white) supremacists in the United States, especially in the South. The blacks, according to Du Bois (1935, as cited in Lemert, 2013) were faced with the effects of chronic racism in the South. This is evident in the differentiated "public and psychological wage" that the "white group of laborers" received in addition to their low wage, as opposed to the "black group of laborers" who suffered structural, psychological and public discrimination (Lemert, 2013, p. 185). In addition, the mainstream media "almost utterly ignored the Negro except in crime and ridicule" (Lemert, 2013, p. 185). The European people had no regard for the African slaves they brought over to America, but their produce was highly appreciated and cherished. The African laborer was "estranged and alienated" from his produce. This experience could be further illustrated using Marx's (as cited in Lemert, 2013) theory of "Estranged Labour" which states that: "The alienation of the worker in his product means not only that his labour becomes an object, an external existence, but that it exists outside him, independently, as something alien to him, and that it becomes a power of its own confronting him; it means that the life which he has conferred on the object confronts him as something hostile and alien" (p. 30). 
The alienation of the African slave from his produce - the very products of his own labor - is highly symbolic in understanding the value attributed to the Africans by their European abductors. The fact that the African slave was stripped of his right to the produce of his labor signifies that his captors considered him not human, but a thing, something lower, a property that could be bought and sold, that could be used or destroyed at will. However, after the abolishment of slavery and the Civil Rights Act of 1964 that officially outlawed racial discrimination in the United Sates, the dynamics of racism in America changed. The engine (or ideology) that inspired and catalyzed racism was transferred from the state and inscribed into the minds, heads, eyes, ears, and hands of some individual European (white) people. Since the state was pressurized to outlaw overt structural racism, structural racism was no longer legal but now illegal.

Just as it is commonly said, "old habits die hard," it is very difficult to change and quit from accustomed and existing behavior or habit in order to adjust to a new way of living - a new culture, a new weltanschauung and a new habit. Since you can't teach an old dog new tricks, it becomes extremely difficult and slow for some European (white) people to abandon racism and embrace a new order of justice and equality. By formal state law and in theory, racism was abolished within the formerly instituted structures of oppression. By informal, accumulated cultural heritage, and in practice, racism metamorphosed from its structural principles to an encrypted form; from the oversight of the state to the jurisdiction of the individual; from its overt and obvious nature to a more concealed, obscure, hidden, secrete, invisible, masked, veiled, and disguised forms. This was the birth of encrypted racism in the United States of America against which the Black Lives Matter movement is militating, protesting and fighting in the twenty-first century.

In the introductory part of this article, stated that the use of the term encrypted racism is inspired by Restrepo and Hincapíe's (2013) "The Encrypted Constitution: A New Paradigm of Oppression," which argues that:

The first purpose of encryption is the disguising of all dimensions of power. With the encryption of technolegal language and, therefore, procedures, protocols and decisions, subtle manifestations of power become undetectable to anyone who does not have the linguistic knowledge to break the encryption. Thus, encryption depends on the existence of a group that has access to the formulae of encryption and another group that completely ignores them. The latter, being unauthorized readers, are open to manipulation. (p. 12) 
From this quotation, one could easily understand the inner characteristics of encrypted racism. First, in an encrypted racist society, there are two groups of people: the privileged group and the unprivileged group. The privileged group members have access to what Restrepo and Hincapíe (2013) call "formulae of encryption" (p. 12) on which the principles of covert or encrypted racism and discriminatory practices are based. Because the privileged group members are those who occupy leadership positions in the public offices and other strategic sectors of the society, and given the fact that they possess the formulae of encryption, that is, the secret codes with which the privileged group members code and decode the algorithm or sets of instruction and patterns of interactions between the privileged and unprivileged groups, or put differently and explicitly, between the whites and blacks in the United States, the white (privileged) people could easily discriminate against and marginalize the African Americans (unprivileged black) people, sometimes without realizing they are being racist. The latter, having no access to the formulae of encryption, the secret sets of information, or the covert codes of operation that circulates within the privileged group, sometimes do not even realize what is happening to them. This explains the nature of the covert, hidden or encrypted racial discrimination that occurs within the education system, housing, employment, politics, media, police-community relations, justice system, and so on. Tyson (2015) indirectly captures the idea of encrypted racism and how it works in the United States by affirming that:

As many Americans of all colors know, however, racism has not disappeared: it's just gone "underground." That is, racial injustice in the United States is still a major and pressing problem; it's simply become less visible than it used to be. Racial injustice is practiced on the sly, so to speak, to avoid legal prosecution, and it has flourished in ways that, in many cases, only its victims really know well. (p. 351)

There are many examples with which one could demonstrate the operations of the encrypted racists. One example is the unreasonable overt and covert opposition of some Republicans to all the policy proposals that President Barack Obama, the first African American President of the United States, introduced. Even after winning the presidential elections in 2008 and 2012, a group of Republicans championed by Donald Trump still argues that President Obama was not born in the United States. Although many Americans do not take Trump seriously, one should question his motives for depriving Obama of his constitutional rights as a United States citizen by birth. Is this not a covert, coded or encrypted way of saying that Obama is not qualified to be the President 
of the United States because he is a black man of African descent and not white enough to be president in a country of which the majority is white?

Another example is the claim that African American critics cite regarding the racial discriminatory practices within the legal and law enforcement systems. "The possession of 28 grams of crack cocaine (used predominantly by black Americans) automatically triggers a five-year mandatory prison sentence. However, it takes 500 grams of powder cocaine (used predominantly by white Americans) to trigger that same fiveyear mandatory prison sentence" (Tyson, 2015, p. 352). In addition, the racially motivated police surveillance of African American neighborhoods and the resultant stop and frisk police brutality and unnecessary shootings of unarmed African Americans could equally be seen as originating from the principles of encrypted racism.

Encrypted racism as it is used in this article shows that the encrypted racist knows and understands the underlying principles of structural racism and violence but cannot overtly and openly discriminate against the African American community because open discrimination and overt structural racism are prohibited and made illegal by the Civil Rights Act of 1964 and other Federal Laws. The Civil Rights Act of 1964 passed by the 88th Congress (1963-1965) and signed into law on July 2, 1964 by President Lyndon B. Johnson ended overt structural racism but, unfortunately, did not end encrypted racism, which is a covert form of racial discrimination. By consistently and gradually mobilizing millions of people not only in the United States but also around the world against the encrypted racist agenda of the white supremacists, the Black Lives Matter movement has succeeded in creating awareness and raising our consciousness to the facts of encrypted racism manifesting itself in many forms, ranging from profiling to police brutality; from citations and arrests to the killings of unarmed African Americans as well as from employment and housing discriminatory practices to racially motivated marginalization and oppression in schools. These are few examples of encrypted racism that the Black Lives Matter movement has helped to decrypt.

\section{DECRYPTING ENCRYPTED RACISM}

That encrypted racism has been decrypted through the activism of the Black Lives Matter movement is not by design, but by serendipity - a term used on January 28, 1754 by Horace Walpole which means "discoveries, by accident and sagacity, of things" not yet known (Lederach 2005, p. 114). It is not by the common intelligence of the founders of the Black Lives Matter movement, but by the agony and pain of the unarmed teenagers and hundreds of black lives that were abruptly cut off through the guns of the self-proclaimed white supremacists in whose hearts is en- 
crypted poisonous hatred toward black lives, and in whose minds, head and brain a decision to kill an unarmed black person has been ignited by reminiscence of the old structures of racism.

It could be argued that police brutality, bias, prejudice and stereotyping against the black race all over the country were also prevalent in the old structures of racism. But the events in Ferguson, Missouri, have given researchers, policymakers, and the general public an in-depth understanding of the nature of encrypted racism. The activism of the Black Lives Matter movement was instrumental in zooming the light of investigation onto the discriminatory practices and killings of unarmed African Americans. The investigation of the Ferguson Police Department conducted and published by the United States Department of Justice Civil Rights Division on March 4, 2015 after the killing of Michael Brown, Jr. reveals that Ferguson law enforcement practices disproportionately harm Ferguson's African-American residents and are driven in part by racial bias, including stereotyping (DOJ Report, 2015, p. 62). The report further explains that Ferguson's law enforcement actions impose a disparate impact on African Americans that violates federal law; and that Ferguson's law enforcement practices are motivated in part by discriminatory intent in violation of the Fourteenth Amendment and other federal laws (DOJ Civil Rights Division Report, 2015, pp. 63 - 70).

Therefore, it is not surprising that the African American community is outraged by the racially motivated practices of the white dominated police force. One question that comes to mind is: could the DOJ Civil Rights Division have investigated the Ferguson Police Department if not for the activism of the Black Lives Matter movement? Probably not. Perhaps, if not for the persistent protests staged by the Black Lives Matter movement, the racially motivated killings of unarmed black people in Florida, Ferguson, New York, Chicago, Cleveland, and in many other cities and states by the police would not have been exposed and investigated. The Black Lives Matter movement could therefore be interpreted as a unique "voice of color"- a critical race concept that holds that "minority writers and thinkers are generally in a better position than white writers and thinkers to write and speak about race and racism because they experience racism directly" (Tyson, 2015, p. 360). Proponents of "voice of color" invites the victims of racial discrimination to tell their stories as they experienced discrimination. The Black Lives Matter movement plays this important role of storytelling, and in doing so, it serves as a twenty-first century call to not only change the current status quo embedded in encrypted racism, but to expose and decrypt what Restrepo and Hincapíe (2013) call the "formulae of encryption" the secret codes with which the privileged group members code and decode the algorithm and patterns of interactions between the privileged and un- 
privileged groups, or put differently and explicitly, between the whites and blacks in the United States (p. 12).

\section{CONCLUSION}

Given the complex and complicated nature of racism in the United States, and considering the limitations the author encountered while collecting data on the numerous cases of violence against black people, most critics may argue that this article lacks sufficient field data (that is, primary sources) on which the arguments and positions of the author ought to be founded. Field research or other methods of data collection are a necessary condition for valid research outcomes and findings, however, one could also argue that they are not a sufficient condition for a critical analysis of social conflicts as has been reflectively done in this article using social conflict theories that are relevant to the subject matter under study.

As noted in the introduction, the main goal this article is to examine and analyze the activities of the "Black Lives Matter" movement and their efforts to uncover the hidden racial discrimination embedded in the institutions and history of the United States in order to create a path for justice, equality and equity for the minorities, especially the African American community. To achieve this goal, the article examined four relevant social conflict theories: "African American Criticism" (Tyson, 2015, p. 344); Kymlicka's (1995) "Multicultural Citizenship: A Liberal Theory of Minority Rights" that recognizes and accords «group-differentiated rights» to particular groups that have suffered historical racism, discrimination and marginalization; Galtung's (1969) theory of structural violence that highlights structures of oppression that prevent a section of the citizenry from having access to their basic human needs and rights thereby forcing people's "actual somatic and mental realizations to be below their potential realizations" (Galtung, 1969, p. 168); and finally Burton's (2001) critique of the "traditional power-elite structure" - a structure typified in the "we-they" mentality-, which holds that individuals who are subjected to structural violence by the institutions and norms inherent in the power-elite structure will definitely respond using different behavioral approaches, including violence and social disobedience.

The analysis of the racial conflict in the United States that this article has successfully done in light of these theories, and with the help of concrete examples reveals a transition or shift from overt structural racism to encrypted racism. This transition occurred because by formal state law and in theory, racism was abolished in the United States. By informal, accumulated cultural heritage, and in practice, racism metamorphosed from its overt structural principles to an encrypted, covert form; it moved from the oversight of the state to the jurisdiction of the 
individual; from its overt and obvious nature to a more concealed, obscure, hidden, secrete, invisible, masked, veiled, and disguised forms.

This concealed, hidden, coded or covert form of racial discrimination is what this article refers to as encrypted racism. This article affirms that just as the Civil Rights Movement was instrumental in ending overt structural racism, open discrimination and segregation in the United States, the Black Lives Matter movement has been bravely instrumental in decrypting encrypted racism in the United States. A particular example could be the events in Ferguson, Missouri, that provided in-depth understanding of the nature of encrypted racism to researchers, policymakers and the general public through the DOJ's Report (2015) that reveals that Ferguson law enforcement practices disproportionately harm Ferguson's African-American residents and are driven in part by racial bias, including stereotyping (p. 62). The Black Lives Matter movement is therefore a unique "voice of color" helping the historically dominated and racially marginalized African Americans to tell their stories as they experienced discrimination (Tyson, 2015, p. 360).

Their stories have been instrumental in decrypting encrypted racism in the United States. However, further research is needed to understand the various ways through which the twenty-first century nonviolent African American activists make their voices heard, and to analyze the challenges they encounter in their activism as well as examine the reaction from the government and the dominant white population.

\section{REFERENCES}

Brammer, J. P. (2015, May 5). Native Americans are the group most likely to be killed by Police. Blue Nation Review. Retrieved from http://bluenationreview.com/

Burton, J. W. (2001). Where do we go from here? The International Journal of Peace Studies, 6(1). Retrieved from http://www.gmu .edu/programs/icar/ijps/vol6_1/Burton4.htm

Black Lives Matter. (n.d.). Retrieved March 8, 2016, from http://black livesmatter.com/about/

Definition of structure in English. (n.d.) In Oxford's online dictionary. Retrieved from http://www.oxforddictionaries.com/us/definition/ american_english/structure

Du Bois W. E. B. (1935). Black reconstruction in America. New York: Atheneum.

Galtung, J. (1969). Violence, peace, and peace research. Journal of Peace Research, 6(3), 167-191. Retrieved from http://www.jstor .org/stable/422690 
Investigation of the Ferguson Police Department. (2015, March 4). United States Department of Justice Civil Rights Division Report. Retrieved March 8, 2016, from https://www.justice.gov/

Kymlicka, W. (1995). Multicultural citizenship: A liberal theory of minority rights. New York: Oxford University Press.

Learner's definition of structure. (n.d.) In Merriam-Webster's online learner's dictionary. Retrieved from http://learnersdictionary.com/ definition/structure.

Lederach, J. P. (2005). The moral imagination: The art and soul of building peace. New York: Oxford University Press.

Lemert, C. (Ed.) (2013). Social theory: The multicultural, global, and classic readings. Boulder, CO: Westview Press.

Restrepo, R. S. \& Hincapíe G. M. (2013, August 8). The encrypted constitution: A new paradigm of oppression. Critical Legal Thinking. Retrieved from http://criticallegalthinking.com/

The 2015 Florida Statutes. (1995-2016). Retrieved on March 8, 2016, from http://www.leg.state.fl.us/Statutes/

Townes, C. (2015, October 22). Obama explains the problem with 'all lives matter.' ThinkProgress. Retrieved from http://thinkprogress .org/justice/

Tyson, L. (2015). Critical theory today: A user-friendly guide. New York, NY: Routledge. 